\title{
Node frequency alters stem biomechanics and hydraulics in four deciduous woody species
}

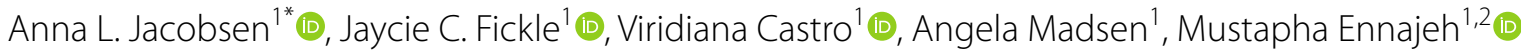 \\ and R. Brandon $\operatorname{Pratt}^{1}$ (D)
}

\begin{abstract}
Along the distal stems of woody plants, nodes occur along the stem length separated by internode regions. Nodes typically include a leaf or leaf scar and an axillary bud that are connected to the xylem tissue within the stem through vascular leaf and bud traces. The diversion of xylem tissue into these lateral appendages creates a node gap that is typically occupied by parenchyma. We hypothesized that node-associated changes in structure within the stem tissues would result in alterations to stem biomechanics and hydraulic transport. We examined four deciduous species, Juglans californica, Populus trichocarpa, Quercus robur, and Rhus aromatica and measured node frequency, stem density, biomechanics, and hydraulic conductivity in 36 stems from each species. Vessel diameters within nodes and internodes were measured on a subset of these stems, as well as measures of xylem, pith, and node gap areas. Increased node frequency was correlated with decreased stem strength (modulus of rupture; MOR), decreased stem stiffness (modulus of elasticity; MOE), increased stem density, and decreased hydraulic conductivity. There were no differences in vessel diameter or xylem area between node and internode regions. Reduced hydraulic conductivity with increasing node frequency could have been due to increased vessel termini associated with nodes as has been found in prior research. Increased length of hydraulic pathways due to divergence of vessels around node gaps could also decrease hydraulic conductivity. Variation within the tree crown in node frequency may be an important morphological feature that has implications for crown tolerance of periodic mechanical stresses, such as wind events and fruit load.
\end{abstract}

Keywords: Biomechanics, Density, Hydraulic conductivity, Hydraulic resistance, Nodes, Node gaps, Xylem

\section{Introduction}

Within developing woody plant stems, nodes occur in regular and ordered locations along the shoot and are the locations from which leaves, lateral shoots, and other lateral modified appendages emerge (Fig. 1). Nodes contrast with internode regions, which do not develop leaves or stems during primary growth. Structurally, nodes typically include a leaf or leaf scar and an associated axillary bud, with those structures connected to the xylem tissue within the stem through vascular leaf and bud traces. The

\footnotetext{
*Correspondence: ajacobsen@csub.edu

${ }^{1}$ Department of Biology, California State University, Bakersfield, CA 93311, USA

Full list of author information is available at the end of the article
}

otherwise vertical xylem tissue diverts radially into lateral appendages and creates a disruption that is typically occupied by parenchyma and is termed the leaf or bud gap. Here, we generalized these terms to node-associated vascular traces ("node traces") and node-associated nonvascular gaps ("node gaps") [1].

Node traces and gaps result in an alteration in the type and arrangements of cells and tissues in the stem that may alter stem biomechanics [1-4] as well as stem hydraulic function $[5,6]$. Biomechanically, this may weaken stems because parenchyma cells, as found in node gaps, are thinner walled and should be less mechanically robust than the thicker walled fibers that are abundant in xylem. Thus, all things being equal, having less xylem at a node gap should lead to weaker tissue. Moreover, reduced
Springer Open

(c) The Author(s) 2020. This article is licensed under a Creative Commons Attribution 4.0 International License, which permits use, sharing, adaptation, distribution and reproduction in any medium or format, as long as you give appropriate credit to the original author(s) and the source, provide a link to the Creative Commons licence, and indicate if changes were made. The images or other third party material in this article are included in the article's Creative Commons licence, unless indicated otherwise in a credit line to the material. If material is not included in the article's Creative Commons licence and your intended use is not permitted by statutory regulation or exceeds the permitted use, you will need to obtain permission directly from the copyright holder. To view a copy of this licence, visit http://creativeco mmons.org/licenses/by/4.0/. 


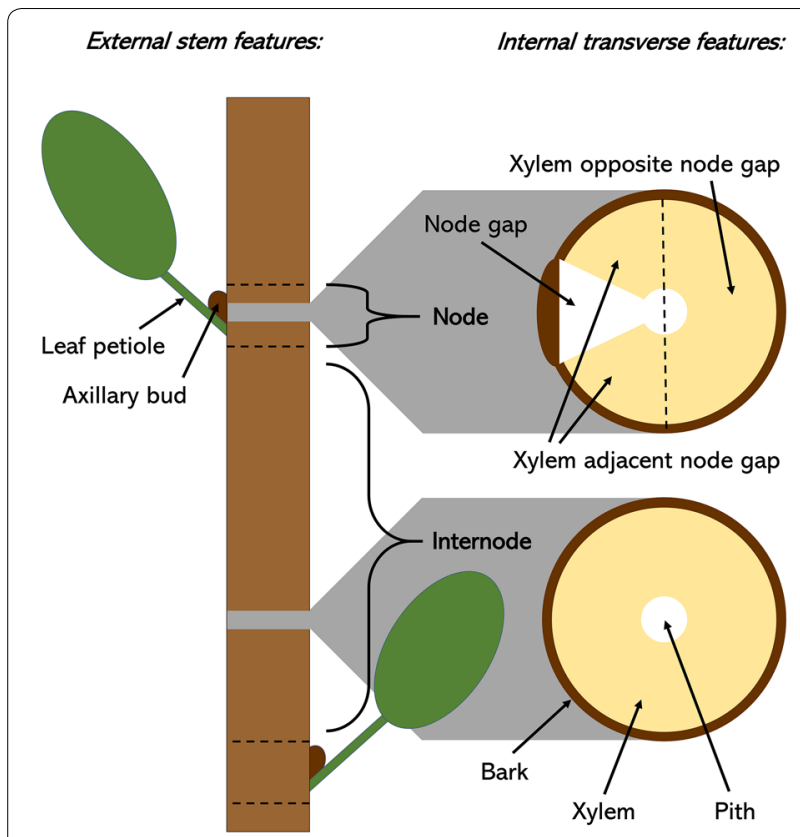

Fig. 1 Anatomical features of nodes within current-year woody shoots

xylem area and xylem rearrangements may lead to lower hydraulic conductivity through nodes, because xylem is the tissue that contains water-transporting vessels. It is also possible that node xylem may compensate or adjust in structure to avoid these predicted changes in strength and conductivity allowing them to display similar values to those found in internodes.

We hypothesized that node-associated changes in structure within the stem tissues would result in alterations to stem biomechanics and hydraulic transport. To examine the influence of nodes on xylem structure, we examined vessel diameters in nodes compared to internodes. Within nodes, we examined the diameter of vessels in the xylem occurring adjacent to the node gap and compared them to vessel diameters in the xylem located opposite of the node gap (Fig. 1). We predicted that increased node frequency would decrease stem stiffness (modulus of elasticity; MOE) and stem strength (modulus of rupture; MOR). We also predicted that increased node frequency would be associated with a decrease in stem density, due to the replacement of dense xylem tissue with an increased proportion of gap-associated parenchyma tissue. Hydraulically, nodes were predicted to increase resistance to flow through the stem (i.e., segments with more nodes would have lower conductivity) due to increased vessel endings at nodes [7], increased path length as the xylem diverts from a linear path around node gaps [4], reduced cross-sectional area of xylem around node gaps, and other potential changes in vessel structure and network arrangements.

\section{Materials and methods \\ Stem samples}

We sampled four deciduous species growing on campus in the Environmental Studies Area at California State University, Bakersfield, USA (Table 1). Two of these species, Populus trichocarpa and Quercus robur, were growing in a well-watered field plot containing several tree species. Trees were spaced at 4- $\mathrm{m}$ increments along rows that were spaced $4 \mathrm{~m}$ apart (see Jacobsen et al. [8] for additional plot information). Two other species, Juglans california and Rhus aromatica, were growing in an adjacent field plot containing many chaparral shrub species. These shrubs were propagated from cuttings or seedlings and had been established for several years at the time of sampling (see Pratt et al. [9] for additional plot

Table 1 Means ( \pm 1 SE) for the biomechanical and hydraulic traits measured across four species, including the frequency of nodes, modulus of elasticity (MOE), modulus of rupture (MOR), stem density, and xylem-specific hydraulic conductivity $\left(K_{\mathrm{s}}\right)$

\begin{tabular}{|c|c|c|c|c|c|c|c|}
\hline Species & & $n$ & Nodes $\left(\# \mathrm{~m}^{-1}\right)$ & $\begin{array}{l}\text { Specific MOE } \\
\left(\mathrm{N} \mathrm{mm}^{-2}\right)\end{array}$ & $\begin{array}{l}\text { Specific MOR } \\
\left(\mathrm{N} \mathrm{mm}^{-2}\right)\end{array}$ & $\begin{array}{l}\text { Stem density } \\
\left(\mathrm{g} \mathrm{cm}^{-3}\right)\end{array}$ & $K_{\mathrm{s}}\left(\mathrm{kg} \mathrm{s}^{-1} \mathrm{MPa}^{-1} \mathrm{~m}^{-1}\right)$ \\
\hline $\begin{array}{l}\text { Juglans californica S. } \\
\text { Watson (Juglan- } \\
\text { daceae) }\end{array}$ & JC & 36 & $60.42 \pm 5.34^{\mathrm{A}}$ & $5156 \pm 254^{C}$ & $85.02 \pm 3.61^{B}$ & $0.4712 \pm 0.008^{C}$ & $0.998 \pm 0.123^{B}$ \\
\hline $\begin{array}{l}\text { Populus trichocarpa } \\
\text { Hook. (Salicaceae) }\end{array}$ & $\mathrm{Pt}$ & 36 & $27.36 \pm 1.94^{\mathrm{B}}$ & $5310 \pm 316^{C}$ & $80.71 \pm 4.35^{B}$ & $0.5689 \pm 0.014^{B}$ & $2.009 \pm 0.146^{A}$ \\
\hline $\begin{array}{l}\text { Quercus robur L. } \\
\text { (Fagaceae) }\end{array}$ & Qr & 36 & $56.25 \pm 4.74^{\mathrm{A}}$ & $9138 \pm 547^{B}$ & $134.76 \pm 6.94^{\mathrm{A}}$ & $0.6575 \pm 0.014^{A}$ & $1.076 \pm 0.146^{\mathrm{B}}$ \\
\hline $\begin{array}{l}\text { Rhus aromatica Aiton } \\
\text { (Anacardiaceae) }\end{array}$ & $\mathrm{Ra}$ & 36 & $37.40 \pm 1.81^{\mathrm{B}}$ & $11,689 \pm 917^{A}$ & $147.84 \pm 10.80^{A}$ & $0.5019 \pm 0.011^{C}$ & $0.269 \pm 0.046^{C}$ \\
\hline
\end{tabular}

The sample size is also included $(n)$. There were significant differences between species in their node number $\left(F_{3,140}=16.85, P<0.001\right), \mathrm{MOE}\left(F_{3,140}=30.76, P<0.001\right)$, $\operatorname{MOR}\left(F_{3,140}=23.79, P<0.001\right)$, stem density $\left(F_{3,140}=46.41, P<0.001\right)$, and $K_{\mathrm{s}}\left(F_{3,140}=34.14, P<0.001\right)$. Different letters following values within in a column indicate significant differences among species 
information). This plot receives supplemental fall and spring irrigation, but experiences a summer dry period.

All samples were collected and measured during March 2019. At this time, sampled species were leafless and had not yet broken bud to initiate spring growth, with the exception of some Rhus samples that exhibited early signs of bud break. Collected stem segments were mostly 1 year old and represented stems and xylem that had formed during the past year's growing season, although a few samples also contained a portion of 2-year-old xylem in order to maintain the necessary segment length for biomechanics measures $(20 \mathrm{~cm})$. These samples were typical vegetative branches and were not specialized or determinate reproductive shoots.

In order to collect samples that varied in the number of nodes occurring within a given length (node density), stem segments were collected from the 4-cardinal directions of each individual (N, S, E, and $\mathrm{W})$ and from different heights with at least 6 and up to 9 individuals sampled per species ( $n=36$ stem segments per species). Long samples $(>0.5 \mathrm{~m})$ were collected in the field, cut from plants underwater, to avoid introducing air into the vascular system, and then transferred to a bucket with their cut ends remaining submerged in water. Samples were immediately transported to the laboratory at California State University, Bakersfield ( $<30 \mathrm{~min})$, and prepared for hydraulic conductivity determination.

\section{Hydraulic conductivity}

The large branches were cut underwater from both ends until a 20 -cm-long unbranched segment was obtained. We targeted stem segments that were 1 year in age, although some segments that had short annual growth increments contained older proximal portions of xylem. Stem ends were shaved using a fresh razor blade for each sample. Bark was not removed from stems. Stem segments were flushed with $20 \mathrm{mM}$ degassed $\mathrm{KCl}$ solution at $100 \mathrm{kPa}$ for $1 \mathrm{~h}$ to remove native emboli present within the xylem vessels. Maximum hydraulic conductivity $\left(K_{\mathrm{h}}\right)$ was measured gravimetrically using a conductivity apparatus [10]. Maximum xylem-specific hydraulic conductivity $\left(K_{\mathrm{s}}\right)$ was calculated by dividing $K_{\mathrm{h}}$ by the xylem cross-sectional area of the distal end of the samples.

\section{Biomechanics and stem density}

Following determination of $K_{\mathrm{s}}$, the same stem segments that had been used for hydraulics measures were loaded into a material properties tester (Model 3342, Instron, Norwood, MA, USA) with parameters set for a 4-point bending test to determine both stem strength (modulus of rupture; MOR) and stiffness (modulus of elasticity; MOE). Calculations followed those of Jacobsen et al. [11]. For each segment, the number of nodes within the measured 20-cm-long segments were counted and used to calculate the number of nodes per stem length $\left(\# \mathrm{~m}^{-1}\right)$.

After biomechanical tests, a 5-cm-long sample of undamaged tissue was excised from the end of each 0.20 - $\mathrm{m}$-long sample for stem density determination. The length and proximal and distal diameters of each sample were carefully measured using digital caliplers. For each segment, the number of nodes contained within the excised $5-\mathrm{cm}$ section were counted. Samples were then dried in an oven (Thermo Scientific Precision 3051 Series, Fisher Scientific, Waltham, MA, USA) at $60{ }^{\circ} \mathrm{C}$ for $\geq 72 \mathrm{~h}$ and weighed to obtain the dry mass. Stem density was calculated as the volume of the stem segment divided by the dry mass.

\section{Anatomy}

For each species, 6 stem segments were randomly selected for additional anatomical measures. Cross-sections were made of both node and internode xylem segments using a sledge microtome (Model 860 Microtome, American Optical Corp., Buffalo, New York, USA). These segments were mounted on slides in glycerol and examined using a light microscope (Axio Imager. D2, Carl Zeiss MicroImaging $\mathrm{GmbH}$, Gottingen, Germany) with an attached digital camera (AxioCam MRc, Carl Zeiss MicroImaging $\mathrm{GmbH}$, Gottingen, Germany). Using an image analysis program (AxioVision, Axio Vs40, v. 4.8.2.0, MicroImaging $\mathrm{GmbH}$, Gottingen, Germany), the area of vessel lumens was measured for more than 50 vessels each from the internode, the region of xylem adjacent to the node, and the region of xylem opposite to the node $(\min =51$, mean $=66, \max =94)$ for each sample. These vessels represented all the vessels in sectors delineated by ray parenchyma bands and extending from the pith to the cambium. In many cases, the measured vessels represented all of the vessels within the entire transverse section. Vessel diameters were calculated from lumen areas using the assumption that vessel lumens were circular.

The same slides were also examined at a lower magnification to measure features of the entire cross-section using a dissecting microscope with an attached digital camera (Zeiss Stereo Discover V.12 with Axiocam HRc digital camera, Carl Zeiss Microscopy, LLC, Thornwood, NY, USA). Using the same image analysis program as above, the cross-sectional area of xylem and pith were measured on both node and internode samples. Within node samples, the cross-sectional area of the node gap was also measured.

\section{Analyses}

The relationships between node frequency and other traits were examined using a general linear model with species and node ${ }^{*}$ species included as an interaction term. 
For biomechanics traits, one-way analysis of variance (ANOVA) analyses were used to compare traits across species with Tukey's post hoc analyses. For vessel diameters, ANOVA analyses were used to compare diameters of the internode, adjacent to the node, and opposite to the node within each species. For xylem and pith areas, paired t-tests were used to compare the area of node versus internodes within each species. Stem density was compared among segments containing 1,2 , and 3 or more $(3+)$ nodes using ANOVA with Tukey's post hoc analyses. All analyses were conducted using Minitab (v. 17.2.1, Minitab, Inc., State College, Pennsylvania, USA).

\section{Results and discussion}

We found large differences in the node frequency of young distal stems in four deciduous species (range of 10 to 130 node $\# \mathrm{~m}^{-1}$ ) (Fig. 2). Quercus robur and Juglans californica had the highest node frequencies (Table 1). We sampled only adult plants from a single plot at a single point in time, but our node frequency range was similar to what was reported across adults, resprouts, irrigated, and non-irrigated plants in a prior study on Juglans californica (10 to $160 \#^{-1}$ ) [4]. This suggests that our sampling protocol was likely able to capture much of the potential difference in node frequency.

\section{Nodes reduced stem biomechanical strength and stiffness}

Across all species, increased node frequency was associated with a significant, but moderate, decrease in stem stiffness and strength (Fig. 3). This relationship was the same across all four species (i.e., the interaction term nodes"species was not significant) (Fig. 3); however, the species differed from one another in their absolute stem biomechanics, with higher strength and stiffness in

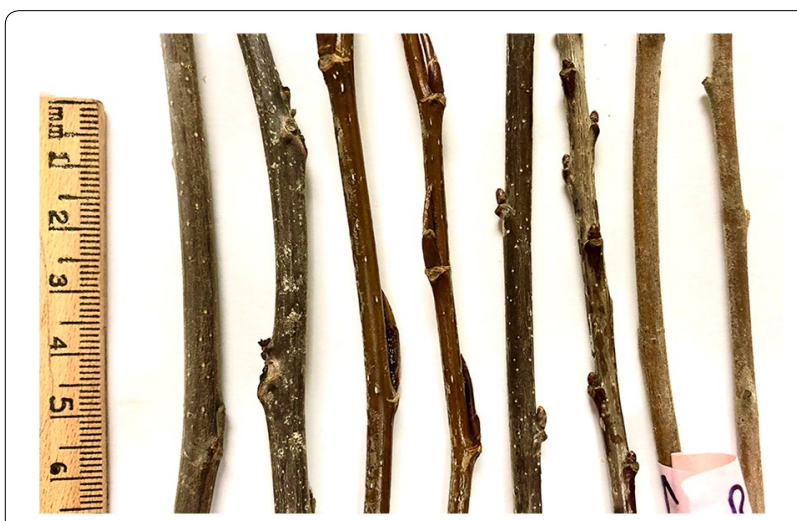

Fig. 2 Samples from each species illustrating some of the variations in node frequency across different shoots. Two stems are included from each species and the species are arranged from left to right as follows: Juglans californica, Populus trichocarpa, Quercus robur, and Rhus aromatica

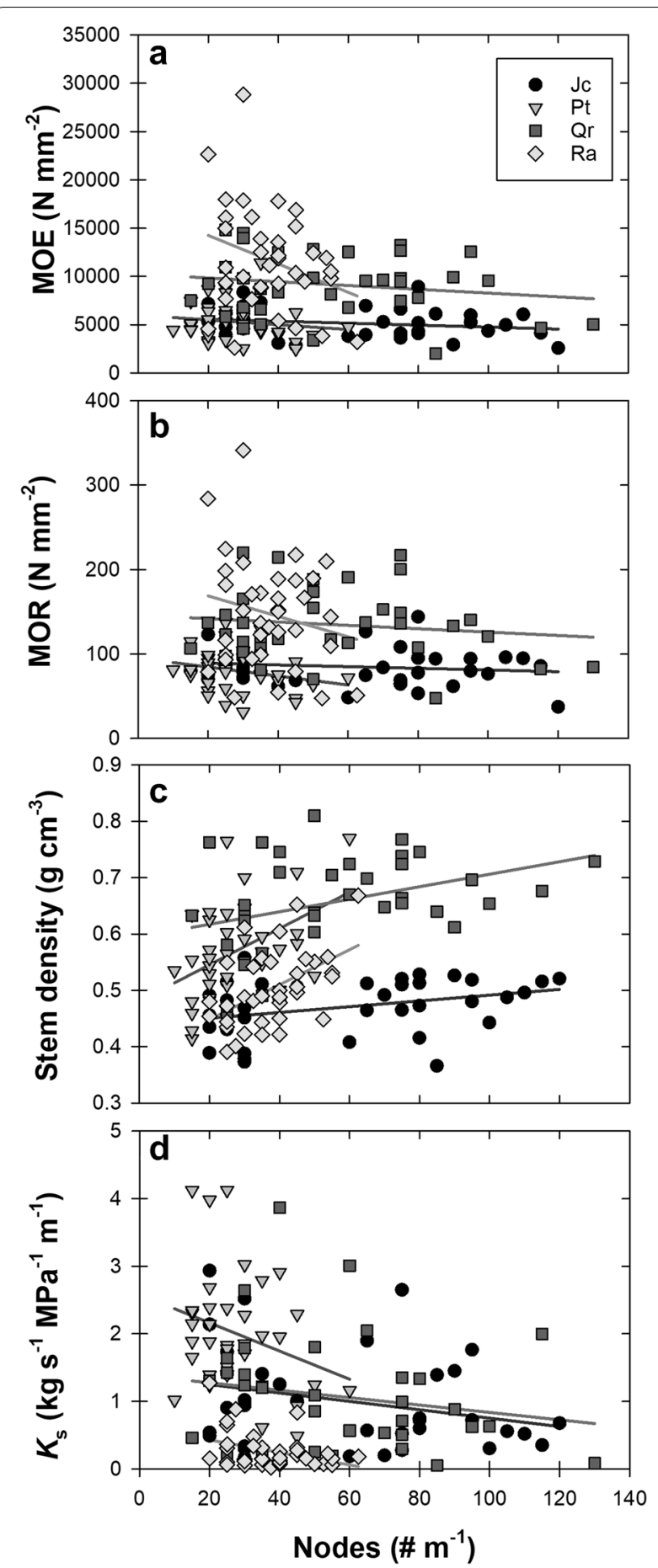

Fig. 3 Modulus of elasticity (MOE), modulus of rupture (MOR), stem density, and xylem-specific hydraulic conductivity $\left(K_{s}\right)$ varied with node frequency. Each point represents a stem sample. Node frequency was associated with $\operatorname{MOE}\left(F_{1,143}=7.00 P=0.009\right), \operatorname{MOR}\left(F_{1,143}=4.63 P=0.033\right)$, stem density $\left(F_{1,143}=27.38 P<0.001\right)$, and $K_{s}\left(F_{1,143}=6.54 P=0.012\right)$. For MOE, MOE, and $K_{s^{\prime}}$ there were no interactions between species $\left(P>0.05\right.$ for node* ${ }^{*}$ species term), but for stem density, there was a significant interaction between species $\left(F_{3,143}=3.74 P=0.013\right)$. Lines are included to assist with the visual interpretation of patterns in the data. Species are indicated with different symbols within each panel and species abbreviations are included in Table 1 
Quercus and Rhus than in Juglans and Populus (Table 1). Stem strength and stiffness were correlated, such that stems that resisted greater force were also stiffer (Fig. 4). This relationship has been found in many interspecific studies of stem traits [11-14].

Alterations in stem biomechanics with increased node frequency and for node regions compared to internodes $[2,4]$ suggests that the rearrangement and altered proportions of tissues in the node weaken the stem. This could be due to decreases in the amount of fibers in the node region as well as the inclusion of more parenchyma, both of which could result in weaker stems. Prior studies have found that stems with a greater proportion of parenchyma generally have lowered MOR and MOE and those with an increased proportion of fibers have increased MOR and MOE [11, 15, 16]; however, these relationships may not hold across all species [17]. Tissue rearrangements around the node gap may also alter the axial alignment of xylem tissues altering its mechanical properties [18]. This is an interesting result, because node gaps are a relatively small cross-sectional area of nodes (Fig. 5) and so both the proportion of parenchyma and xylem and the deflection of xylem around the node gap were relatively minor.

\section{Nodes reduced stem hydraulic conductivity}

Hydraulic conductivity declined with increasing node frequency (Fig. 3), as has been described in Fagus sylvatica [19]. Reductions in hydraulic conductivity have also been described for branch junctions, which represent nodes that have developed lateral appendages [20]. A decline in conductivity with node frequency could be due to vessel diameter changes within the node; however, vessel diameter was generally unchanged between node and

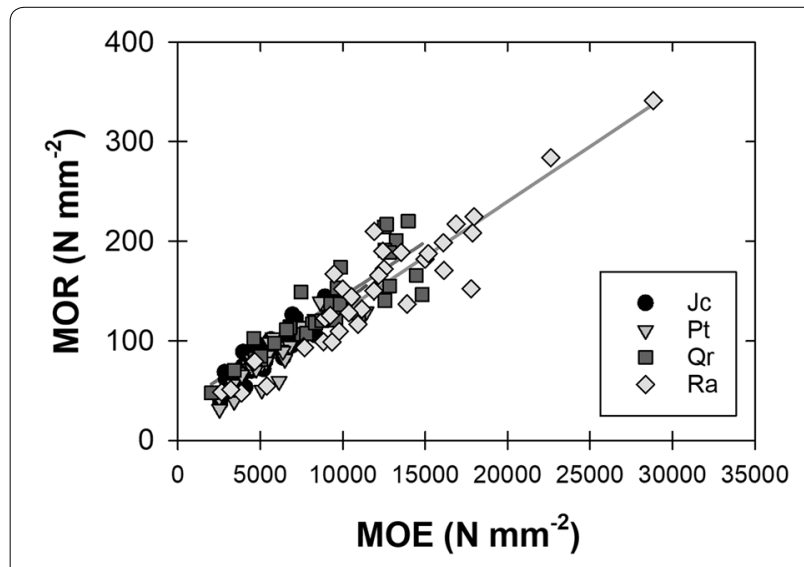

Fig. 4 Modulus of elasticity (MOE) and modulus of rupture (MOR) were strongly correlated $\left(F_{1,143} P<0.001\right)$. Species abbreviations are included in Table 1 internode regions. Only two species, Populus and Rhus, displayed differences in vessel diameters between vessels located adjacent to or opposite from the node gap within the node, and no species displayed differences in vessel diameter between node and internode regions (Table 2). This suggests that changes in hydraulic conductivity with node number are not likely to be due to changes in vessel structure, although increased vessel terminations within nodes [21] may result in increased hydraulic resistance.

It may be that decreases in hydraulic conductivity were due to a decrease in the cross-sectional area of the xylem through nodes; however, we did not find a significant difference in the xylem area of nodes versus internodes for any species (Table 3). Although the node gap represents a relatively small proportion of stem cross-sections within our sampled species (Fig. 5; Table 3), this may be enough to increase hydraulic resistance, especially when there are many nodes within a stem segment. Additionally, the addition of curvature around node gaps may increase the path length of sap through the xylem, which would also decrease conductivity.

\section{Stem density increased with increased numbers of nodes}

For the relationship between node frequency and stem density, there was a significant interaction between species. Although species displayed different slopes for this relationship, the direction was similar across all species; stem density increased with increased node frequency (Fig. 3). We examined this relationship at a finer scale, since stem density was only measured on a short $5-\mathrm{cm}$ segment of our 20-cm-long samples. When limited to a comparison of node number within these smaller segments, the same pattern was also evident (Fig. 6). This pattern is consistent with other studies, including an increase in stem density with node frequency in Juglans californica in Bergman et al. [4] and denser and biomechanically weaker nodes compared to internodes in $\mathrm{Cer}$ cis occidentalis [2].

Across species, denser stem tissue is usually associated with increased strength $[13,15,16,22,23]$; however, this relationship appears reversed when higher density is due to node frequency. Bergman et al. [4] suggested that this was due to the need for nodes to be flexible and able to respond to wind loads, particularly when bearing leaves or axillary branches. Regardless, this relationship is interesting and may explain some of the variation in the relationship between density and biomechanics found in some studies (e.g., Woodrum et al. [17]).

\section{Conclusion}

The frequency of nodes along distal stems altered the density, biomechanical properties, and hydraulic traits of the stem xylem. Node gaps likely lead to increased 

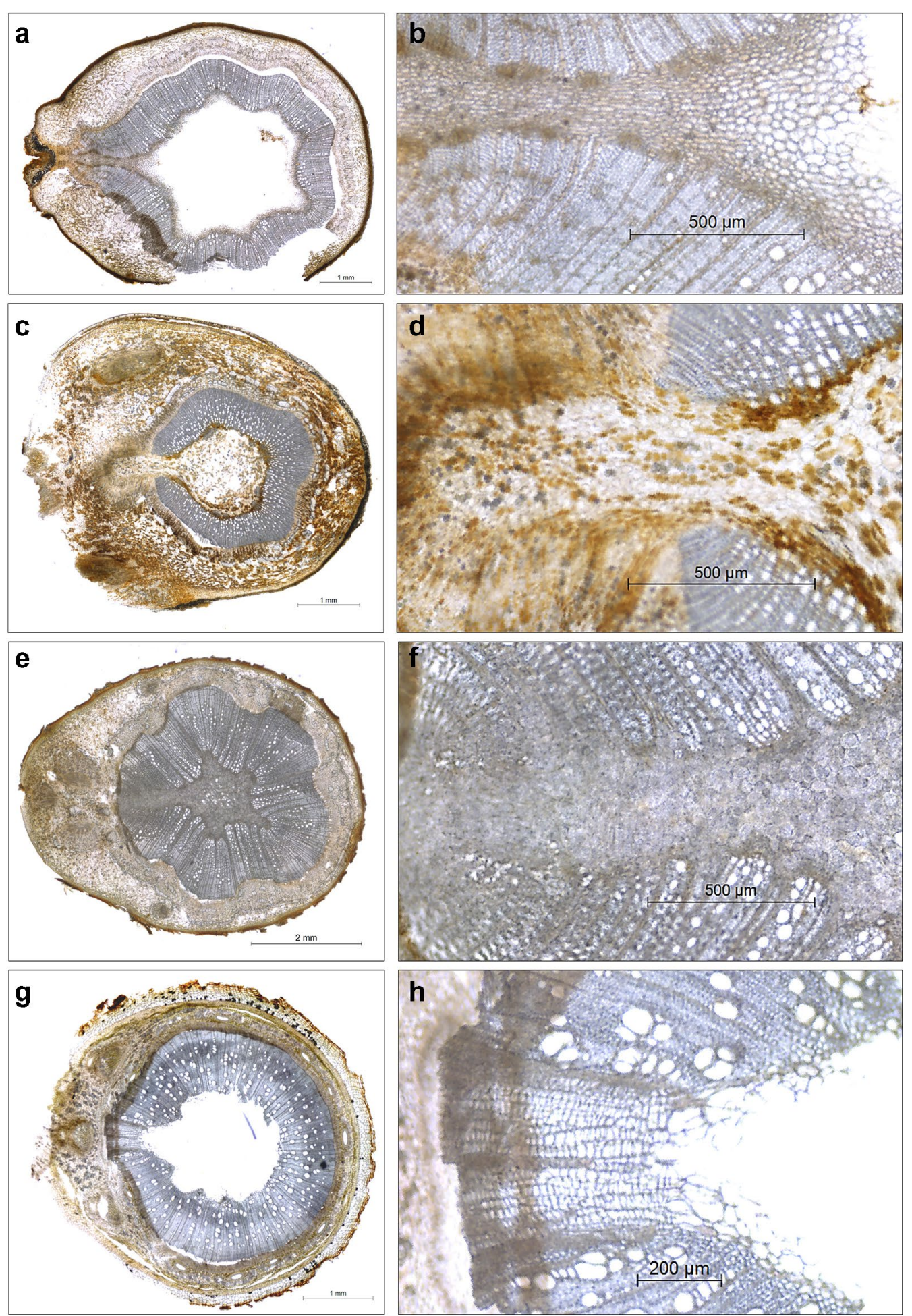

Fig. 5 Representative micrographs of stem transverse sections and node gaps of four species, including Juglans californica (a, b), Populus trichocarpa $(\mathbf{c}, \mathbf{d})$, Quercus robur $(\mathbf{e}, \mathbf{f})$, and Rhus aromatica $(\mathbf{g}, \mathbf{h})$. In all panels, a scale bar is included 
Table 2 Means ( \pm 1 SE) for anatomical traits measured within nodes and internodes of four species, including mean and maximum vessel diameters from xylem in the internode, from adjacent to the node gap in the node, and from opposite of the node gap in the node

\begin{tabular}{|c|c|c|c|c|}
\hline & Juglans californica & Populus trichocarpa & Quercus robur & Rhus aromatica \\
\hline \multicolumn{5}{|c|}{ Mean vessel diameter ( $\mu \mathrm{m})$} \\
\hline Internode & $34.22 \pm 3.17$ & $20.29 \pm 1.39$ & $21.77 \pm 1.12$ & $19.03 \pm 2.88$ \\
\hline \multicolumn{5}{|l|}{ Node } \\
\hline Adjacent node gap & $29.95 \pm 1.59$ & $18.37 \pm 0.65$ & $22.53 \pm 1.00$ & $21.55 \pm 1.26$ \\
\hline Opposite node gap & $33.19 \pm 2.65$ & $20.62 \pm 1.05^{*}$ & $22.90 \pm 1.12$ & $21.98 \pm 3.10$ \\
\hline \multicolumn{5}{|c|}{ Maximum vessel diameter ( $\mu \mathrm{m})$} \\
\hline Internode & $71.72 \pm 6.41$ & $42.03 \pm 1.49$ & $50.74 \pm 2.78$ & $58.44 \pm 4.30$ \\
\hline \multicolumn{5}{|l|}{ Node } \\
\hline Adjacent node gap & $66.56 \pm 5.53$ & $40.59 \pm 1.90$ & $53.60 \pm 4.41$ & $54.55 \pm 3.72$ \\
\hline Opposite node gap & $76.60 \pm 9.26$ & $44.22 \pm 1.69$ & $54.42 \pm 5.04$ & $61.25 \pm 3.51^{* *}$ \\
\hline
\end{tabular}

There were no significant differences in vessel diameters between nodes and internodes $(P>0.05$ for all). Within the node, two species displayed differences in vessel diameters adjacent to and opposite from the node gap $\left({ }^{*} P=0.03,{ }^{* *} P<0.001\right)$

Table 3 Means ( \pm 1 SE) for cross-sectional areas of stems measured within nodes and internodes of four species, including mean xylem area and mean pith area for the node and internode regions

\begin{tabular}{|c|c|c|c|c|}
\hline & Juglans californica & Populus trichocarpa & Quercus robur & Rhus aromatica \\
\hline \multicolumn{5}{|c|}{ Mean xylem area $\left(\mathrm{mm}^{2}\right)$} \\
\hline Internode & $15.54 \pm 3.11$ & $7.14 \pm 1.60$ & $11.43 \pm 1.73$ & $11.16 \pm 2.59$ \\
\hline Node & $14.94 \pm 2.73$ & $7.00 \pm 1.54$ & $10.77 \pm 1.67$ & $11.41 \pm 2.26$ \\
\hline \multicolumn{5}{|c|}{ Mean pith area $\left(\mathrm{mm}^{2}\right)$} \\
\hline Internode & $3.33 \pm 0.48$ & $2.35 \pm 0.53$ & $2.68 \pm 0.78$ & $3.63 \pm 0.86$ \\
\hline Node & $3.90 \pm 0.50$ & $2.33 \pm 0.55$ & $2.55 \pm 0.82$ & $4.24 \pm 0.81^{*}$ \\
\hline \multicolumn{5}{|l|}{ Node gap } \\
\hline Area $\left(\mathrm{mm}^{2}\right)$ & $0.51 \pm 0.17$ & $0.28 \pm 0.04$ & $0.44 \pm 0.09$ & $0.81 \pm 0.26$ \\
\hline Cross-section (\%) & $2.46 \pm 0.40$ & $3.16 \pm 0.32$ & $3.22 \pm 0.56$ & $4.36 \pm 0.68$ \\
\hline
\end{tabular}

For node regions, the mean cross-sectional area of the node gap and the percentage cross-sectional area of the node gap relative to the entire area are also reported. There were no significant differences in xylem area between node and internode regions within species $(P>0.05$ for all). For pith areas, one species displayed differences in pith area between node and internode regions $\left({ }^{*} P=0.006\right)$ and there were no differences for the other species $(P>0.05)$

path length in the hydraulic transport pathway and a divergence of fibers from the axial orientation that typifies the internode. These changes increase the density of the tissue, but biomechanically weaken it. Examination of stems that vary in their node frequency may be an interesting way to examine structure-function relationships, particularly related to changes in the vessel network that are influenced by node gap-driven rearrangements in xylem tissue. Variation within the tree crown in node frequency may be an important morphological feature that has implications for crown tolerance of periodic mechanical stresses, such as wind. 


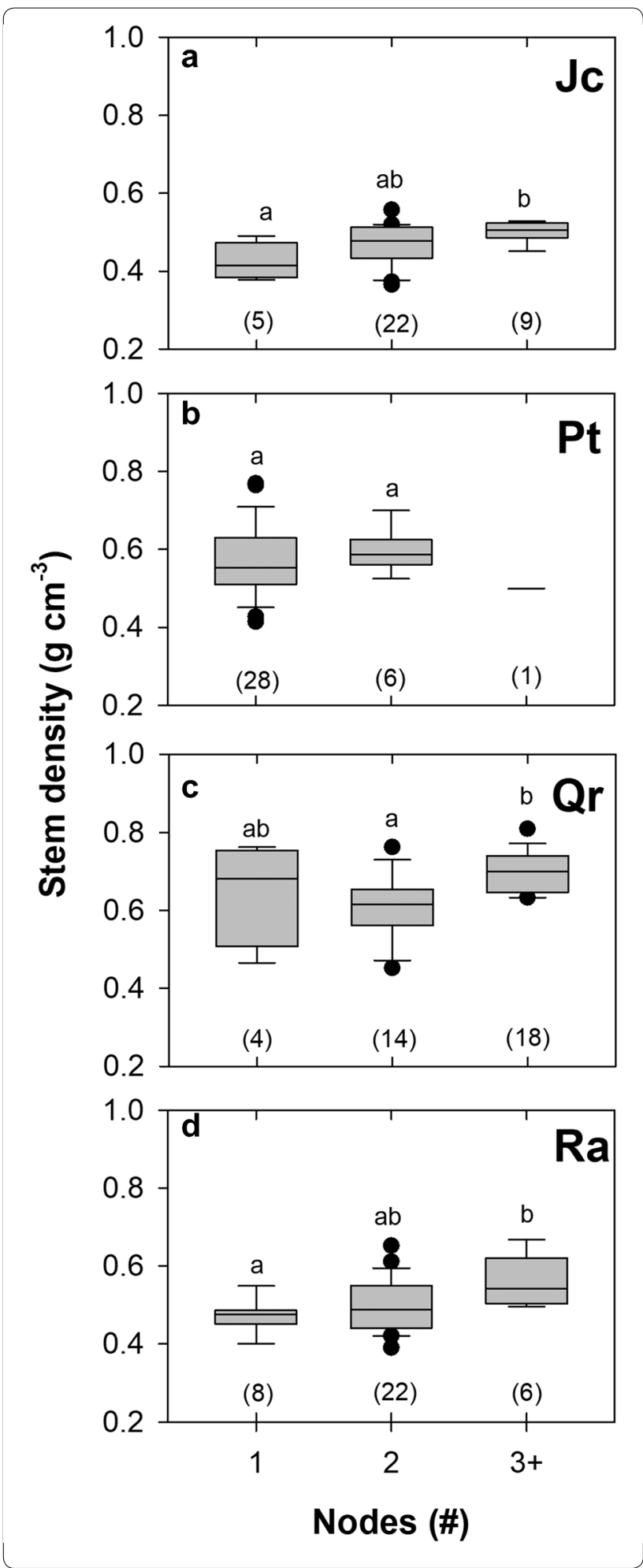

4 Fig. 6 Stem density of 5 -cm stem segments that included 1, 2, and 3 or more $(3+)$ nodes within the segment. For each box (grey), the center line represents the median, the grey box represents 25 and $75 \%$ data boundaries, the whiskers represent 10 and 90\% data boundaries, and black circles represent the 5 and $95 \%$ data boundaries. For some species and node numbers, sample sizes precluded the calculation of all of these parameters. Same sizes are included for each box in the parentheses within a panel. For three species, there were significant differences in stem density among segments with different numbers of nodes (JC $F_{2,33}=3.60 P=0.038$, Qr $F_{2,33}=5.82 P=0.007$, and $\left.\operatorname{Ra} F_{2,33}=3.44, P=0.044\right)$ and there was no differences for the fourth species ( $P t F_{233}=0.65 P=0.530$ ). Within a panel, different letters indicate significant differences in stem density with the number of nodes. Species abbreviations are included in Table 1

\section{Abbreviations}

$K_{h}$ : Hydraulic conductivity; $K_{s}$ : Xylem-specific hydraulic conductivity; MOE: Modulus of elasticity; MOR: Modulus of rupture.

\section{Acknowledgements}

This project was initiated as part of a course-based research experience (CURE) project for Introductory Biology — Plants (BIOL 2120) during the Spring 2019 semester at California State University, Bakersfield, and all students are acknowledged for their assistance with node counts, biomechanics, and stem density measures.

\section{Authors' contributions}

ALJ planned the experiment and led analyses and writing; all co-authors contributed to the experimental design, collected and analyzed data. All authors read and approved the final manuscript.

\section{Funding}

National Science Foundation (NSF) grants IOS-1252232 and HRD-1547784 and the Fulbright Program of Tunisia and United States Department of State supported this research.

\section{Availability of data and materials}

All data generated and analyzed during this study are included in this article.

\section{Ethics approval and consent to participate}

Not applicable.

\section{Consent for publication}

Not applicable.

\section{Competing interests}

The authors declare that they have no competing interests.

\section{Author details}

1 Department of Biology, California State University, Bakersfield, CA 93311, USA. ${ }^{2}$ Laboratory of Biodiversity and Valorization of Bioresources in Arid Zones, Faculty of Sciences of Gabès, University of Gabès, 6072 Gabès, Tunisia.

Received: 4 December 2019 Accepted: 1 April 2020 Published online: 08 April 2020 


\section{References}

1. Bergman BA, Bobich EG, Davis SD, Utsumi Y, Ewers FW (2018) Dense but flexible wood-how leaf nodes impact xylem mechanics in Juglans californica. IAWA J 39:372-381. https://doi.org/10.1163/22941932-20170205

2. Niklas KJ (1997) Responses of hollow, septate stems to vibrations: biomechanical evidence that nodes can act mechanically as spring-like joints. Ann Bot 80:437-448. https://doi.org/10.1006/anbo.1997.0463

3. Caringella MA, Bergman BA, Stanfield RC, Ewers MM, Bobich EG, Ewers FW (2014) Effects of phyllotaxy on biomechanical properties of stems of Cercis occidentalis (Fabaceae). Am J Bot 101:206-210. https://doi. org/10.3732/ajb.1300260

4. Taylor D, Kinane B, Sweeney C, Sweetnam D, O'Reilly P, Duan K (2015) The biomechanics of bamboo: investigating the role of the nodes. Wood $\mathrm{Sci}$ Technol 49:345-357. https://doi.org/10.1007/s00226-014-0694-4

5. Tyree MT, Graham MED, Cooper KE, Bazos LJ (1983) The hydraulic architecture of Thuja occidentalis. Can J Bot 61:2105-2111. https://doi. org/10.1139/b83-226

6. Meinzer FC, Goldstein G, Neufeld HS, Grantz DA Crisosto GM (1992) Hydraulic architecture of sugarcane in relation to patterns of water use during plant development. Plant Cell Environ 15:471-477. https://doi. org/10.1111/j.1365-3040.1992.tb00998.x

7. Nijsse J (2004) On the mechanism of xylem vessel length regulation. Plant Physiol 134:32-34. https://doi.org/10.1104/pp.103.032334

8. Jacobsen AL, Valdovinos-Ayala J, Rodriguez-Zaccaro FD, Hill-Crim MA, Percolla MI, Venturas MD (2018) Intra-organismal variation in the structure of plant vascular transport tissues in poplar trees. Trees 32:1335-1346. https //doi.org/10.1007/s00468-018-1714-z

9. Pratt RB, Mackinnon ED, Venturas MD, Crous CJ, Jacobsen AL (2015) Root resistance to cavitation is accurately measured using a centrifuge technique. Tree Physiol 35:185-196. https://doi.org/10.1093/treephys/tpv003

10. Sperry JS, Donnelly JR, Tyree MT (1988) A method for measuring hydraulic conductivity and embolism in xylem. Plant Cell Environ 11:35-40. https:// doi.org/10.1111/j.1365-3040.1988.tb01774.x

11. Jacobsen AL, Ewers FW, Pratt RB, Paddock WA III, Davis SD (2005) Do xylem fibers affect vessel cavitation resistance? Plant Physiol 139:546-556. https://doi.org/10.1104/pp.104.058404

12. Onoda Y, Richards AE, Westoby M (2010) The relationship between stem biomechanics and wood density is modified by rainfall in 32 Australian woody plant species. New Phytol 185:493-501. https://doi.org/10.111 1/j.1469-8137.2009.03088.x

13. Méndez-Alonzo R, Paz H, Zuluaga RC, Rosell JA, Olson ME (2012) Coordinated evolution of leaf and stem economics in tropical dry forest trees. Ecology 93:2397-2406. https://doi.org/10.1890/11-1213.1
14. Van Duong D, Matsumura J (2018) Within-stem variations in mechanical properties of Melia azedarach planted in northern Vietnam. J Wood Sci 64:329-337. https://doi.org/10.1007/s10086-018-1725-9

15. Pratt RB, Jacobsen AL, Ewers FW, Davis SD (2007) Relationships among xylem transport, biomechanics and storage in stems and roots of nine Rhamnaceae species of the California chaparral. New Phytol 174:787-798. https://doi.org/10.1111/j.1469-8137.2007.02061.x

16. Jacobsen AL, Agenbag L, Esler KJ, Pratt RB, Ewers FW, Davis SD (2007) Xylem density, biomechanics and anatomical traits correlate with water stress in 17 evergreen shrub species of the Mediterranean-type climate region of South Africa. J Ecol 95:171-183. https://doi.org/10.111 1/j.1365-2745.2006.01186.x

17. Woodrum CL, Ewers FW, Telewski FW (2003) Hydraulic, biomechanical, and anatomical interactions of xylem from five species of Acer (Aceraceae). Am J Bot 90:693-699. https://doi.org/10.3732/ajb.90.5.693

18. Lachenbruch B, McCulloh KA (2014) Traits, properties, and performance: how woody plants combine hydraulic and mechanical functions in a cell, tissue, or whole plant. New Phytol 204:747-764. https://doi.org/10.1111/ nph. 13035

19. Rust S, Hüttl RF (1999) The effect of shoot architecture on hydraulic conductance in beech (Fagus sylvatica L.). Trees 14:39-42. https://doi. org/10.1007/s004680050005

20. Ewers FW (1985) Xylem structure and water conduction in conifer trees, dicot trees, and lianas. IAWA J 6:309-317. https://doi.org/10.1163/22941 932-90000959

21. Salleo S, Gullo ML, Siracusano L (1984) Distribution of vessel ends in stems of some diffuse-and ring-porous trees: the nodal regions as'safety zones' of the water conducting system. Ann Bot 54:543-552. https://doi. org/10.1093/oxfordjournals.aob.a086825

22. Niklas KJ (1992) Plant biomechanics: an engineering approach to plant form and function. University of Chicago Press, Chicago

23. Van Gelder HA, Poorter L, Sterck FJ (2006) Wood mechanics, allometry, and life-history variation in a tropical rain forest tree community. New Phytol 171:367-378. https://doi.org/10.1111/j.1469-8137.2006.01757.x

\section{Publisher's Note}

Springer Nature remains neutral with regard to jurisdictional claims in published maps and institutional affiliations.

\section{Submit your manuscript to a SpringerOpen ${ }^{\circ}$ journal and benefit from:}

- Convenient online submission

- Rigorous peer review

- Open access: articles freely available online

- High visibility within the field

- Retaining the copyright to your article

Submit your next manuscript at $\boldsymbol{\nabla}$ springeropen.com 